\title{
Water-based Vaginal Lubricant
}

National Cancer Institute

\section{Source}

National Cancer Institute. Water-based Vaginal Lubricant. NCI Thesaurus. Code C102539.

A water-based vaginal lubricant with hydration activity. Upon application to the vagina, the water-based vaginal lubricant provides moisture and may relieve dryness and sexual discomfort. 